\title{
CHANGES IN THE SAGITTAL BALANCE IN CONGENITAL SCOLIOSIS CORRECTION SURGERY
}

\author{
ALTERAÇÕES DO EQUILÍBRIO SAGITAL NA CIRURGIA DE CORREÇÃO \\ DE ESCOLIOSE CONGÊNITA
}

\section{CAMBIOS EN EL EQUILIBRIO SAGITAL EN LA CIRUGÍA DE CORRECCIÓN DE LA ESCOLIOSIS CONGENITA}

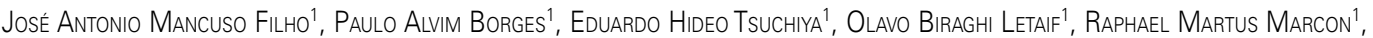 \\ Alexandre Fogaça Cristante ${ }^{2}$ \\ 1. Universidade de São Paulo, Faculty of Medicine, Hospital das Clinicas, Institute of Orthopedics and Traumatology, São Paulo, SP, Brazil. \\ 2. Universidade de São Paulo, Faculty of Medicine, Department of Orthopedics and Traumatology, São Paulo, SP, Brazil.
}

\begin{abstract}
Objective: This study aimed to determine whether surgery leads to changes in sagittal balance in patients with congenital scoliosis. Methods: We retrospectively reviewed all cases of scoliosis operated in a tertiary hospital between January 2009 and January 2013 . In all cases the deformity in the coronal and sagittal planes, kyphosis, and lordosis were measured, using the Cobb method, and spinopelvic parameters: pelvic incidence (PI), sacral slope (SS), and pelvic tilt (PT). Results: A hundred and eleven medical records were analyzed, but the sample resulted in 10 patients, six of whom were females $(60 \%)$. The average age was 13.4 years. In the comparative analysis between pre and postoperative, only the coronal deformity (12.37; Cl 95\% [7.88-16.86]; $\mathrm{p}<0.001)$, the sagittal deformity (12.71; Cl 95\% [4.21-21.22]; $p=0.011)$, and the lumbar lordosis (9.9; $\mathrm{Cl} 95 \%$ [0.38-19.42]; $p=0.043)$ showed significant change. Conclusion: There was no change in the spinopelvic parameters of patients with congenital scoliosis undergoing surgery at IOF-FMUSP between 2009 and 2013 ; however, it was observed decrease in lumbar lordosis, and deformity angle in the sagittal and coronal planes.
\end{abstract}

Keywords: Scoliosis; Spine; Congenital abnormalities; Spinal fusion; Postural balance.

\section{RESUMO}

Objetivos: Este estudo tem como objetivo esclarecer se existe alteração do equilíbrio sagital provocada pela intervenção cirúrgica nos pacientes com escoliose congênita. Métodos: Foram analisados retrospectivamente todos os casos de escoliose operados em um hospital terciário entre janeiro de 2009 e janeiro de 2013. Em todos os casos foram mensuradas a deformidade no plano coronal e sagital, a cifose e lordose, utilizando-se o método de Cobb, e também os parâmetros espinopélvicos: incidência pélvica (PI), inclinação sacral (SS), inclinação pélvica (PT). Resultados: Foram analisados 111 prontuários, porém a amostra resultou em 10 pacientes, dos quais seis eram do sexo feminino (60\%). A média de idade foi de 13,4 anos. Na análise comparativa entre pré e pós-operatório, apenas a deformidade coronal (12,37; IC 95\% [7,88-16,86]; $p$ < 0,001), a deformidade sagital (12,71; IC 95\% [4,21-21,22]; $p=0,011)$ e a lordose lombar (9,9; IC 95\% $[0,38-19,42] ; p=0,043)$ apresentaram alteração significativa. Conclusão: Não foi encontrada alteração nos parâmetros espinopélvicos dos pacientes com escoliose congênita submetidos à intervenção cirúrgica no IOT-FMUSP entre 2009 e 2013, contudo, foi observada diminuição da lordose lombar, do ângulo da deformidade no plano sagital e no plano coronal.

Descritores: Escoliose; Coluna vertebral; Anormalidades congênitas; Fusão vertebral; Equilíbrio postural.

\section{RESUMEN}

Objetivo: Este estudio tiene por objetivo aclarar si hay cambio de equilibrio sagital causado por la cirugía en pacientes con escoliosis congénita. Métodos: Se revisaron retrospectivamente todos los casos de cirugía de escoliosis en un hospital terciario entre enero de 2009 y enero de 2013. En todos los casos se midieron la deformidad en el plan coronal y sagital, la cifosis y lordosis, utilizando el método de Cobb, y también los parámetros espinopélvicos: incidencia pélvica (IP), pendiente sacra (PS), inclinación pélvica (IP). Resultados: Se analizaron 111 registros médicos, pero la muestra resultó en 10 pacientes, de los cuales 6 eran del sexo femenino (60\%). La edad promedio fue de 13,4 años. En el análisis comparativo entre el pre y postoperatorio, solamente la deformidad coronal $(12,37 ;$ IC 95\% [7,88-16,86]; $p<0,001)$, la deformidad sagital (12,71; IC 95\% [4,21-21,22]; $p=0,011)$ y la lordosis lumbar (9,9; IC 95\% [0,38-19,42]; $p=0,043)$ mostraron cambios significativos. Conclusión: No hubo cambios en los parámetros espinopélvicos de los pacientes con escoliosis congénita sometidos a cirugía en IOT-FMUSP entre 2009 y 2013, sin embargo se observó disminución de la lordosis lumbar y del ángulo de deformidad en el plano sagital y plano coronal.

Descriptores: Escoliosis; Columna vertebral; Anomalías congénitas; Fusión vertebral; Balance postural.

\section{INTRODUCTION}

Sagittal balance has been the theme of various studies in recent years. Its importance includes not only maintenance of the biomechanical balance of the spine, decreasing unnecessary energy expenditure, but also the occurrence of a positive postoperative outcome, with a decrease in pain and a lower incidence of failure of the synthesis material. ${ }^{1-3}$ 
Scolioses are degenerative diseases that are often the target of research into the importance of sagittal balance. It is observed that patients with significant changes in the postoperative sagittal angles have a greater chance of requiring review surgeries, and a higher incidence of lumbalgia. ${ }^{4,5}$

Congenital scolioses are spinal deformities resulting from defects in vertebral formation or segmentation, or a combination of these defects. They have an estimated incidence of 0.13 to $0.5 / 1000$ births. ${ }^{6}$ They often generate severe, progressive curves with significant angulation, but due to the lower occurrence of this type of deformity compared to others, there is less information available in the literature on its behavior. ${ }^{7,8}$ Another factor that hinders its study is the great heterogeneity between cases, which makes grouping types of scoliosis difficult. A significant number of patients with this pathology require spinal surgery.

So far, there are no studies that demonstrate the impact of surgical intervention on changes in sagittal balance and its radiographic parameters in patients with congenital scoliosis.

The aim of this study is to clarify whether there are changes in sagittal balance caused by surgical intervention in patients with congenital scoliosis.

\section{METHOD}

A retrospective analysis was carried out of all cases of scoliosis operated on in the Institute of Orthopedics at Hospital das Clínicas of São Paulo (IOT-HCFMUSP) between January 2009 and January 2013, chosen by continuous convenience sampling.

Patients without congenital scoliosis were excluded, as were patients with inadequate radiographic records, whether pre- or postoperative. The position adopted by the patients for the panoramic radiographs followed the conventional positioning protocol used for digital teleradiographs. , $^{9,10}$

Adequate radiographic records were considered panoramic radiographs of the spine in lateral view that include the limits of vertebra $\mathrm{C} 7$ and the femoral head.

In all cases, the deformity was measured in the coronal and sagittal planes, as well as the kyphosis and lordosis, using the Cobb method, ${ }^{11}$ and the spinal-pelvic parameters, ${ }^{1,12,13}$ defined as follows: (Figure 1)

Pelvic Incidence - PI, measured by the angle formed by the lines traced from the midpoint between the centers of the femoral heads and the central point of the superior plateau of S1 and a line perpendicular to the superior plateau from S1, drawn from its central point.

Sacral slope - SS, measured from the angle formed by the horizontal plane and the line drawn tangent to the superior plateau of S1.

Pelvic tilt - PT, measured from the angle formed by the lines drawn from the midpoint between the centers of the femoral heads and the central point of the superior plateau of S1 and from the vertical plumb line to this point.

Lumbar Lordosis - measured from the angle formed by the lines tangent to the inferior plateau of $L 5$ and the upper plateau of $L 1$.

Thoracic kyphosis - measured from the angle formed by the lines tangent to the inferior plateau of T12 and the superior plateau of T2.

The three first angles described are known as spinal-pelvic parameters, and the pelvic incidence is a constant and intrinsic measure of each individual, which is calculated by the sum of the sacral slope and pelvic tilt, according to the formula $(\mathrm{PI}=\mathrm{SS}+\mathrm{PT})$. All the measurements were calculated in degrees.

All the measurements were performed by a single researcher, uniformly, using the digital visualization system iSite-Philips ${ }^{(\mathrm{TM})}$ for the digital radiographs, and a simple goniometer for non-digitalized radiographs. ${ }^{11,14}$ Radiographs dated immediately before and immediately after the surgical procedure were selected. (Figure 2)

The data analysis was performed through the calculation of measurements of median and mean distribution and comparison between pre- and postoperative samples, by the t test of the variables measured above. The normalities of all the variables were evaluated by the Kolgomorov-Smirnov test. The analyses were performed by a statistician who did not take part in the data collection. This research was approved by the Institutional Review Bureau, CAPPesq, of Hospital das Clínicas of the FMUSP, with opinion no. 1,378,110; protocol registration IOT number 1047.

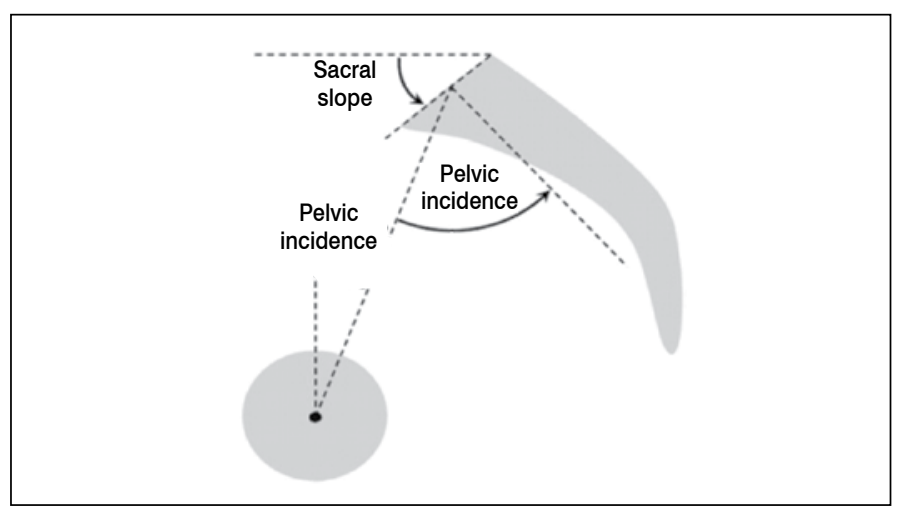

Figure 1. Spinal-pelvic parameters.

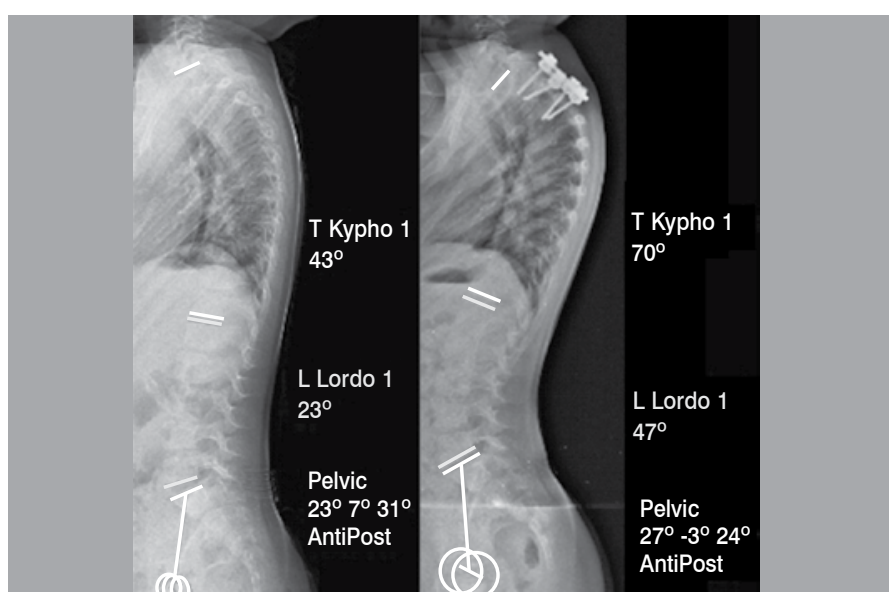

Figure 2. Example of measuring.

\section{RESULTS}

One hundred and eleven patient records were analyzed, of which 12 were for patients with congenital scoliosis. Two cases were excluded before the data analysis, due to the lack of images to enable measuring.

The final sample consisted of 10 patients, four male (40\%) and six female $(60 \%)$. In five patients, the deformity was caused by the presence of a hemivertebra (50\%), with one case between T1-T2, one between T9-T10, one between T7-T8 and two between T12-L1, and in five, by the presence of an intervertebral bar (50\%) with two cases between T7-T8, two between T12-L1 and one between L1-L2. The average age was 13.4 years (5-21 years; Cl 95\% 13.44 [10.2-16.6]) with a median of 13.50. All the patients were operated on once only, the majority by the posterior route $(90 \%)$. (Table 1 )

In all cases, fixation was performed by posterior instrumentation, fixing the vertebrae of the apex of the deformity and at least its adjacent vertebrae, both upper and lower.

The preoperative and postoperative data obtained, which were used for comparison, are listed in Table 2.

In the comparative analysis between pre- and postoperative data, only the coronal deformity $(p<0,001)$, sagittal deformity $(p=0.011)$ and lumbar lordosis $(p=0.043)$ presented significant changes when submitted to the t test. (Table 3 )

\section{DISCUSSION}

Sagittal balance consists of the angulations of the vertebral spine itself, such as the thoracic kyphosis and lumbar lordosis, and the relationship between the pelvis and the spine. ${ }^{5}$ The latter was not widely studied until recently, and has proven to be an important variable of 
Table 1. Characteristics of the sample.

\begin{tabular}{c|c|c|c|c}
\hline & Mean & Median & Cl 95\% & Proportion \\
\hline Age & $13.40[5-21]$ & 13.50 & $\begin{array}{c}13.44 \\
{[10.20-16.60]}\end{array}$ & \\
\hline $\begin{array}{c}\text { Sex (Female) } \\
\begin{array}{c}\text { Cause of the deformity } \\
\text { (hemivertebra) }\end{array}\end{array}$ & & & & $40 \%$ \\
\hline $\begin{array}{c}\text { Cause of the deformity } \\
\text { (Bar) }\end{array}$ & & & & $50 \%$ \\
\hline
\end{tabular}

Table 2. Pre- and postoperative measurements.

\begin{tabular}{c|c|c|c}
\hline & Mean & Median & CI 95\% \\
\hline Preoperative & \multicolumn{3}{|c}{} \\
\hline Coronal deformity & $65.50[32-108]$ & 62.50 & $65.00[33.51-97.49]$ \\
\hline Sagittal deformity & $63.67[23-112]$ & 64.50 & $63.24[32.44-94.89]$ \\
\hline Pelvic incidence & $45.17[31-60]$ & 44.50 & $45.13[34.94-55.39]$ \\
\hline Sacral slope & $37.67[27-44]$ & 40.00 & $37.91[31.42-43.92]$ \\
\hline Pelvic tilt & $7.50[1-25]$ & 5.00 & $6.89[-1.81-16.81]$ \\
\hline Thoracic kyphosis & $22.83[6-50]$ & 18.00 & $22.26[2.37-43.30]$ \\
\hline Lumbar Lordosis & $48.50[39-57]$ & 49.50 & $48.56[40.30-56.70]$ \\
\hline Postoperative & \multicolumn{3}{|c}{} \\
\hline Coronal deformity & $53.38[13-100]$ & 56.50 & $53.03[29.52-77.23]$ \\
\hline Sagittal deformity & $50.67[23-100]$ & 44.00 & $49.46[23.20-78.13]$ \\
\hline Pelvic incidence & $43.50[26-56]$ & 45.00 & $43.78[31.47-55.53]$ \\
\hline Sacral slope & $24.17[14-48]$ & 18.50 & $23.41[10.32-38.02]$ \\
\hline Pelvic tilt & $19.33[6-41]$ & 13.50 & $18.87[4.39-34.27]$ \\
\hline Thoracic kyphosis & $22.83[10-40]$ & 21.50 & $22.59[8.86-36.81]$ \\
\hline Lumbar lordosis & $37.33[20-49]$ & 38.50 & $37.65[25.81-48.86]$ \\
\hline
\end{tabular}

Table 3. Comparative analysis between groups.

\begin{tabular}{c|c|c|c}
\hline \multicolumn{4}{c}{ Comparative analysis between pre- and postoperative groups } \\
\hline & Mean & Cl 95\% & P value \\
\hline Coronal Deformity & 12.375 & $7.885-16.865$ & $\mathrm{p}<0.001$ \\
\hline Sagittal deformity & 12.714 & $4.209-21.219$ & $\mathrm{p}=0.011$ \\
\hline Pelvic incidence & 1.4 & $(-9.678)-12.478$ & No Significant \\
\hline Sacral slope & 7.8 & $(-3.709)-19.309$ & No Significant \\
\hline Pelvic tilt & -6.4 & $(-17.473)-4.673$ & No Significant \\
\hline Thoracic kyphosis & 6.4 & $(-3.427)-16.227$ & No Significant \\
\hline Lumbar lordosis & 9.9 & $0.383-19.417$ & $\mathrm{p}=0.043$ \\
\hline
\end{tabular}

analysis in that an abnormality in this variable plays a fundamental role in the development and progression of various spinal diseases. ${ }^{15}$

The sample included a total of 10 individuals, with a higher proportion of females, and an average age of 13.4 years. There was an equal proportion between the patients who presented hemivertebrae and intervertebral bar. Despite the correction of deformities on both the coronal and sagittal planes, we did not observe any significant change in the spinal-pelvic indices after the surgical intervention. However, the lumbar lordosis was significantly changed after surgery, suggesting that there was no influence in the overall spinal sagittal balance.

Studies have demonstrated that the decrease in lumbar lordosis is an event that should be avoided, as it is related to higher levels of pain and failure in long posterior arthrodesis in adult patients. ${ }^{3,16-18}$ There is still no evidence on the relationship between lumbar lordosis and clinical outcomes or negative surgeries in children or adolescents.

This study presents a small sample number of cases analyzed. In general, this is a common limitation with congenital disorders, and congenital scoliosis is no exception.

Another point to be considered in the analysis of the results is the age of the patients in this sample group. The average age of 13.4 months shows a predominantly female group with a greater tendency to skeletal maturity. It can be presumed that perhaps surgical interventions performed early on may have a more significant impact on the changes in variables of radiographic analysis.

It was not an objective of this work to evaluate quality of life or patient satisfaction with the surgical procedure. This is a limitation of the study, in that it does not show the impact that the change in lumbar lordosis had on the clinical symptoms of these patients. It was also not possible to infer whether or not the other radiological variables that do not undergo changes represented a negative impact on the quality of life of the individuals.

Given the absence of scientific articles in the literature analyzing sagittal balance and congenital scoliosis, this is a new and pioneering study.

New studies focusing on this theme, with larger population samples, are imperative. Future works that analyze sagittal balance in congenital scoliosis can identify changes in the other sagittal parameters, and enable better therapeutic planning of patients.

\section{CONCLUSION}

No changes were found in the spinal-pelvic parameters of patients with congenital scoliosis submitted to surgical intervention in the IOT-FMUSP between 2009 and 2013; however, a decrease was observed in lumbar lordosis, and in the angle of deformity in the sagittal plane and coronal planes.

All the authors declare no potential conflicts of interest regarding this article.

CONTRIBUTIONS OF AUTHORS: Each author made a significant and individual contribution to the development of the manuscript. JAMF and OBL were the main contributors to the writing of the manuscript. EHT collected the clinical date. PAB evaluated the data from the statistical analysis. RMM and AFC performed the bibliographic research and review of the manuscript, and contributed to the intellectual concept of the study.

\section{REFERENCES}

1. Mac-Thiong JM, Labelle $H$, Roussouly P. Pediatric sagittal alignment. Eur Spine J. 2011;20(Suppl 5):586-90

2. Li WS, Li G, Chen ZQ, Wood KB. Sagittal plane analysis of the spine and pelvis in adult idiopathic scoliosis. Chin Med J (Engl). 2010:123(21):2978-82.

3. Glassman SD, Bridwell K, Dimar JR, Horton W, Berven S, Schwab F. The impact of positive sagittal balance in adult spinal deformity. Spine (Phila Pa 1976). 2005;30(18):2024-9.

4. Cho KJ, Suk SI, Park SR, Kim JH, Kang SB, Kim HS, et al. Risk factors ofm sagittal decompensation after long posterior instrumentation and fusion for degenerative lumbar scoliosis. Spine (Phila Pa 1976). 2010:35(17):1595-601.

5. Mehta VA, Amin A, Omeis I, Gokaslan ZL, Gottfried ON. Implications of spinopelvic alignment for the spine surgeon. Neurosurgery. 2012;70(3):707-21.

6. Giampietro PF. Genetic aspects of congenital and idiopathic scoliosis. Scientifica (Cairo). 2012;2012:152365

7. Louis ML, Gennari JM, Loundou AD, Bollini G, Bergoin M, Bernard JC, et al. Congenita scoliosis: a frontal plane evaluation of 251 operated patients 14 years old or older at follow-up. Orthop Traumatol Surg Res. 2010;96(7):741-7.

8. Giampietro PF, Blank RD, Raggio CL, Merchant S, Jacobsen FS, Faciszewski T, et al. Congenital and idiopathic scoliosis: clinical and genetic aspects. Clin Med Res. 2003:1(2):125-36.

9. Morvan G, Mathieu P, Vuillemin V, Guerini H, Bossard P, Zeitoun F, et al. Standardized way for imaging of the sagittal spinal balance. Eur Spine J. 2011;20(Suppl 5):602-8.

10. Horton WC, Brown CW, Bridwell KH, Glassman SD, Suk SI, Cha CW. Is there an optima patient stance for obtaining a lateral $36^{\prime \prime}$ radiograph? A critical comparison of three techniques. Spine (Phila Pa 1976). 2005;30(4):427-33.

11. Cobb J. Outline for the study of scoliosis. Instr Course Lect. 1948:5:261-75.

12. Tanguay F, Mac-Thiong JM, de Guise JA, Labelle H. Relation between the sagittal pelvic and lumbar spine geometries following surgical correction of adolescent idiopathic scoliosis. Eur Spine J. 2007:16(4):531-6

13. Mac-Thiong JM, Labelle H, Berthonnaud E, Betz RR, Roussouly P. Sagittal spinopelvic balance in normal children and adolescents. Eur Spine J. 2007;16(2):227-34.

14. Kuklo TR, Potter BK, Schroeder TM, O'Brien MF. Comparison of manual and digital measurements in adolescent idiopathic scoliosis. Spine (Phila Pa 1976). 2006;31(11):1240-6.

15. Legaye J, Duval-Beaupère G, Hecquet J, Marty C. Pelvic incidence: a fundamental pelvic parameter for three-dimensional regulation of spinal sagittal curves. Eur Spine J. 1998;7(2):99103.

16. Glassman SD, Berven S, Bridwell K, Horton W Dimar JR Correlation of radiographic parameters and clinical symptoms in adult scoliosis. Spine (Phila Pa 1976). 2005;30(6):682-8.

17. Farcy JP, Schwab FJ. Management of flatback and related kyphotic decompensation syndromes. Spine (Phila Pa 1976). 1997:22(20):2452-7.

18. Booth KC, Bridwell KH, Lenke LG, Baldus CR, Blanke KM. Complications and predictive factors for the successful treatment of flatback deformity (fixed sagittal imbalance). Spine (Phila Pa 1976). 1999;24(16):1712-20 